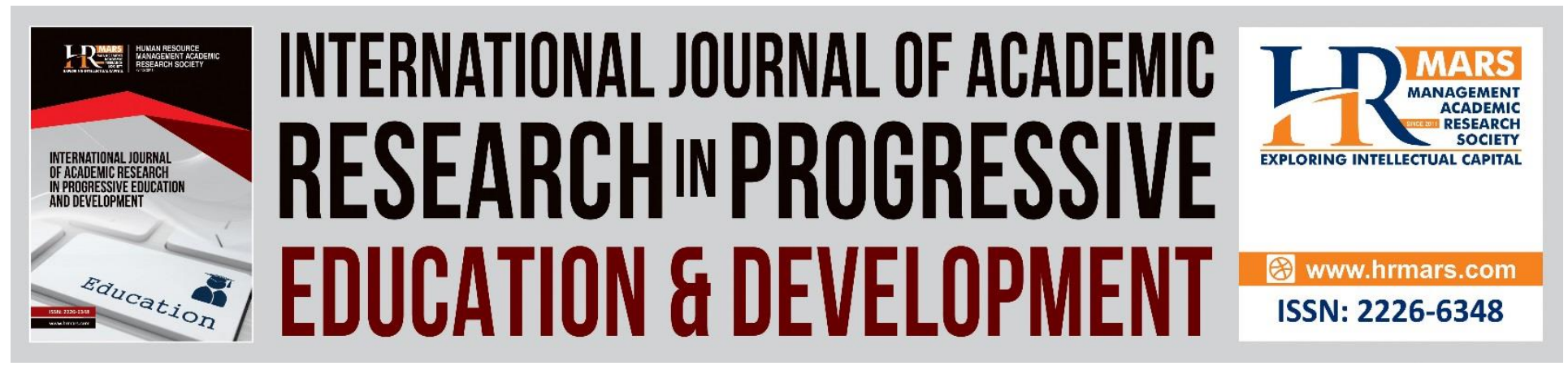

\title{
Knowledge of Social Work Students on Incest
}

Nuraminah Nabihah Ab. Mannan, Nur Saadah Mohamad Aun \& Fauziah Ibrahim

To Link this Article: http://dx.doi.org/10.6007/IJARPED/v10-i1/9683 DOI:10.6007/IJARPED/v10-i1/9683

Received: 07 January 2021, Revised: 10 February 2021, Accepted: 28 February 2021

Published Online: 23 March 2021

In-Text Citation: (Mannan et al., 2021)

To Cite this Article: Mannan, N. N. A., Aun, N. S. M., \& Ibrahim, F. (2021). Knowledge of Social Work Students on Incest. International Journal of Academic Research in Progressive Education and Development, 10(1), 748757.

Copyright: (C) 2021 The Author(s)

Published by Human Resource Management Academic Research Society (www.hrmars.com)

This article is published under the Creative Commons Attribution (CC BY 4.0) license. Anyone may reproduce, distribute, translate and create derivative works of this article (for both commercial and non-commercial purposes), subject to full attribution to the original publication and authors. The full terms of this license may be seen at: http://creativecommons.org/licences/by/4.0/legalcode

Vol. 10(1) 2021, Pg. 748 - 757

http://hrmars.com/index.php/pages/detail/IJARPED JOURNAL HOMEPAGE

Full Terms \& Conditions of access and use can be found at http://hrmars.com/index.php/pages/detail/publication-ethics 


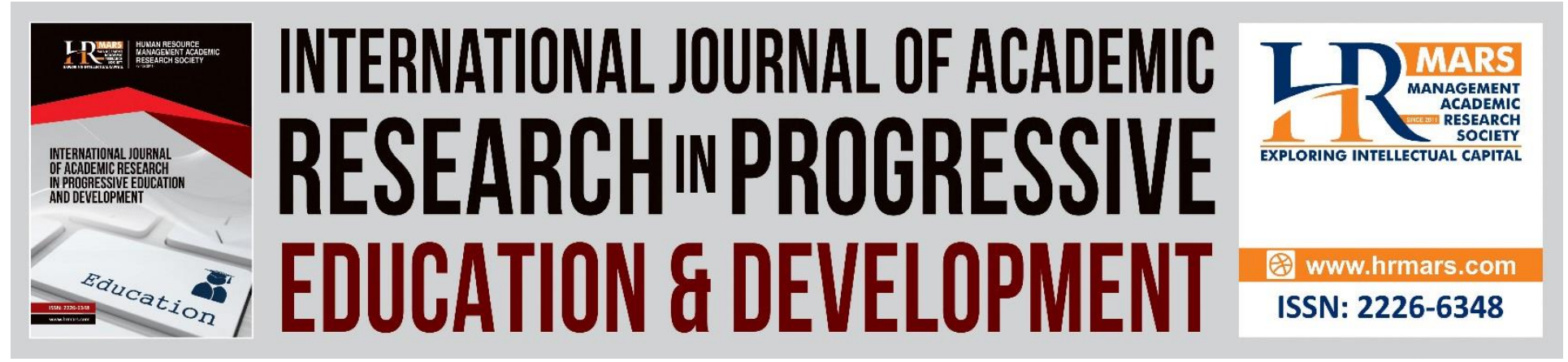

\title{
Knowledge of Social Work Students on Incest
}

\author{
Nuraminah Nabihah Ab. Mannan, Nur Saadah Mohamad Aun \& \\ Fauziah Ibrahim \\ Social Work Program, Centre for Research in Psychology and Human Well-Being, Faculty of \\ Social Sciences and Humanities, Universiti Kebangsaan Malaysia \\ Email: n_saadah@ukm.edu.my
}

\begin{abstract}
Incest is one of the most common sexual abuse cases in Malaysia, even overseas. In this regard, apart from the role parents need, students need to be familiar with this issue as they are the human capital that will shape the nation in the future. This study was conducted to identify knowledge of the Social Work students' program on incest. The study design used was qualitative in the form of semi structured interview techniques. A total of five respondents from the Social Work program students were selected to interview. The data for this study will be thematically analyzed to identify the students' knowledge from Social Work program on incest amongst the children. The results obtained from this study showed that students need to have high knowledge in incest. The findings also show how students get information and keep up to date on incest cases. In this regard, the knowledge of incest should be known to the public in order to sensitize the issue, this problem is no longer a taboo to be discussed in Malaysian society.
\end{abstract}

Keywords: Knowledge, Incest, Student, Social Work, Malaysia

\section{Introduction}

Lately, nearly everyday we are fed with news related to sexual abuse among children. Sexual abuse in our country is not an unusual phenomenal as it could happen to anyone across ages, anywhere. However, what's more frustrating is when there are still the mentalities of Malaysian that consider this sexuality issue as something taboo. This mentality would actually only cause the victim feel ashamed and hard for them to gain justice. This issue is more worrying when this sexual abuse could also happen within a family and is classified as incest. Incest cases that are currently happening nowadays shows that family institution in Malaysia is weakening and indirectly would invite to more social problems. This could also be the cause to the effort in protecting the children as outlined in The Child Act 2001, difficult to be implemented. 'Haruan Makan Anak' is a proverb that is always linked with incest. Among the incest case that has given a deep impact to Malaysian is the one in 2017, when a father has been charged with 623 charges due to raping and sodomising his own child. What is more heartbreaking is when the father of 3 
has raped his first child since 2015 and this disgusting deed happened while they are performing their umrah in the holy land of Mecca. The case got a wide coverage not only within the local media but also caught the attention of international media. This case nonetheless has opened the eyes of the society not to look at incest lightly.

Knowledge in incest not only need to be known among the parents but also need to be applied to the whole society. This is because, the society's concern is the main key to reduce sexual abuse cases in our country. In this case, apart from the parents' role, students also need to pay attention on issues concerning incest as they are the human capital that will design the future of this country. According to Hamat and Naim (2012), human capital is related with efficiency, experience, potential and also capacity. This shows that students could be the agent to the future change in building new principles to enhance efforts in protecting children. In Malaysia, we are well informed that there are a lot of shelter-homes available to protect the children that are the victims of sexual abuse. According to Pathmanathan and Hajar (2010), Children's Shelter-Home is a 'safe place' not only focuses in care, nurture and shelter, but also teaches and socialise children so that they grow up becoming a productive society. Apart from the government's effort building shelter-homes in every state, there're also NGO bodies that are also working together with the government helping these abused children.

\section{Literature Review Knowledge}

Incest is among the cases categorised under children's sexual abuse, however, until now this case is still less reported to the authority. This proves that the society's knowledge in incest is still low. According to Idham et al (2015), there are still in the society that thought these sexual issues shouldn't be debated in public. As a result, those who are less exposed with the correct information about sex will prone to assume and believe on myths compared to actual facts (Idham et al., 2015). According to Hajar and Omar (2010), awareness on children sexual abuse issue is increasing, however, the awareness among the children itself is still low. As we all know, children are a naïve creature and are clueless. Due to that, children are always taken advantage on things related to sexual. According to Radford et al. (2011), most children victim were not aware that they were raped until they grow up. This happened because these children were not given knowledge on sexuality education. According to Halstead and Reiss (2003), sexuality education is meant to give exposure to children on how to handle sexual problem and also to avoid themselves from sexual abuse. Ismail (2010) also argue, sexuality education is very important as every human being naturally has desire, urge and sexual desire. Hence, knowledge in sexuality becomes the main support among children so that they become more aware with their surrounding and know about what needs to be done if they are disturbed sexually.

Parents also have to take the initiative to know on any signs of changes experienced by the children. According to Vezina, Daigneault \& Hebert (2013), one of the reasons for incest cases not reported to the authority is maybe because parents are not trained on how to recognized signs of sexual abuse. This should not happen in a family institution as parents are the most trusted individual to children. Cossar et al. (2012) stated, many children didn't inform in a simple way when they are involved in sexual abuse as they tend to express it through their behavior and 
attitude to give indication on what they are experiencing at that moment. This statement is also aligned with statement by Warrington et al. (2017) because according to him, children are actually aware on the importance of them informing on what they are experiencing, however they just can't afford to reveal it. Due to that, apart from knowing the signs of changes on the children, parents should also have the knowledge on sexuality education so that they could give the early knowledge on it to their children. Besides that, according to Ahmad (2012), less concern and knowledge among the society on social problems is one of the reasons for the widespread of sexual abuse cases. Abeid et al. (2015) opined, the higher the education level, the more in the society will have knowledge in sexual abuse. So, it is clear that knowledge on incest should be known not only to the children and the parents, but also the whole society has to play a role in making sure that this case doesn't continually widespread. Knowledge gained is not only to add on to general current issues knowledge, but it will also function for the society to be more alert to their surroundings. This is because, according to Jennifer (2017), society will not report cases on sexual abuse if they didn't really recognize the physical evidence experienced by the sexual abuse victim. Hence, society need to have the knowledge on this issue so that they know what needs to be done if this happens to the people near them.

\section{Research Methodology}

This research uses a qualitative method and interview technique that involves a few university students of Researcher program using this method because qualitative method is used to understand on a phenomenal and context of a research without manipulating the real situation. The research strategy applied by the researcher in this research is case study. According to Chua (2006), case study is used to gain detailed information on individual and social behaviour. Researcher has chosen University Kebangsaan Malaysia (UKM) as a research location because UKM is one of higher education institution in Malaysia that offers Social Work program. Besides that, researcher is also interested to know are students of Social Work aware of current issues and social ills that is wide- spreading in our society. Generally, we know that Social Work is a profession that is very closely related with society issues. Due to that, researcher chooses this research location to get information about the knowledge of the Social Work students on incest among children. Researcher has used thematic analysis to analyze data gathered. Thematic analysis is a method in describing data and research information that is in qualitative form. Data analysis was started with a process of producing a transcript and further involving the produce of sub theme and theme that is used to support the discussion of research output.

\section{Findings and Discussion \\ Respondent Data Profile}

In this research, researcher has done a research on 5 respondents. Respondent data profile shown is gained from interviews done. A few ethics is complied with during the whole interview and the information details of the interview and recordings is not revealed unless it is for the purpose of this research. 
INTERNATIONAL JOURNAL OF ACADEMIC RESEARCH IN PROGRESSIVE EDUCATION AND

DEVELOPMENT

Vol. 10, No. 1, 2021, E-ISSN: 2226-6348 @ 2021 HRMARS

\begin{tabular}{llll}
\hline Respondent & Gender & Age & Year of Study \\
\hline 1 & Female & 21 & 1 \\
2 & Female & 22 & 2 \\
3 & Male & 22 & 2 \\
4 & Female & 23 & 3 \\
5 & Male & 23 & 3 \\
\hline
\end{tabular}

Based on Table 1, we could see that female respondents are more, than male respondents; that are 3 versus 2. Other than that, in average, the age of the respondents interviewed is between 21 until 23. While in terms of year of study, there are 2 people from third, 2 from second year and only 1 person from first year.

\section{Knowledge about Incest}

Based on interviews done on all 5 respondents, researcher found out that all 5 respondents have high knowledge on incest among children. Understanding on incest need to be awared among the society regardless age level. However, this issue needs to be known more by the university students as they are the youth that will form the next generation. This is because, according to Muhammad Khairul and Nur 'Athiroh (2017), a good youth could lead other people such as family, children and society. Due to that, there are 3 basic themes under the main theme, that is; university students know that incest is a sexual relationship among family members, willingness in doing the intercourse and this most often than not happens in a problematic family.

i. Sexual Intercourse within Family Members

Based on interviews done, researcher found out that all respondents could explain the definition of incest well.

"...incest is about sexual case within close family. Like a father raping his child, a brother rapes his own sister. Something like that".

(Respondent 1)

"Incest is, aaa..from what I know, it has something to do with forbidden relationship between family members. It usually happens between siblings or aaa.... father and children".

(Respondent 2)

"...incest is a forbidden relationship or a sexual intercourse between siblings in a family

(Respondent 3)

"...incest is a sexual intercourse whether willingly or unwillingly but it involves family".

(Respondent 4)

"...incest is when there is a relationship, aaa...sexual among family maybe between child and father or between own siblings".

(Respondent 5)

Outcome from the interviews done, researcher found out that majority of the respondents has a good knowledge on the definition and meaning of incest. All the respondents stated that incest is a sexual intercourse done within the same family members. It is aligned with the definition given by Asmida, Asro \& Sulaiman (2017), that is, incest is a sexual relationship 
within family, or marriage ties that would never happen among them according to the law. This has proven that incest is nothing strange among the university student.

ii. Willingness in doing sexual intercourse among family members.

According to the data gained, there are respondents that stated incest is an unwilling relationship and it could be a willing relationship. This could be seen from answers given by respondent 4 and 5.

"...incest is a sexual intercourse whether willingly or unwillingly but it involves family".

(Respondent 4)

"...incest is when there is a relationship, aaa...sexual among family maybe between child and father or between own siblings".

(Respondent 5)

We are always fed with news on incest that is caused by force from the offender towards the victim. However, have we ever thought that incest could happen with the willingness of both? Recently, we have been shocked with a case of a female teenager that has given birth to a baby from her relationship with her own brother. The willingness could also be due to the victim are afraid of reporting of the relationship to people close to her. According to Idham et al (2015), incest incident has the tendency to recur when the offender influence or threaten the victim to continue keep silent. He also opined that it is difficult to figure out this as it is a secret that usually happen through persuasion and not physical abuse. This incident probably initially happens with force, however, if it happens recurringly, the victim may think that this is something usual to them until a willing relationship happens to them.

iii. Incest Happens in a Problematic Family

The researcher also found out that there are respondents who stated that incest always happens in a problematic family who faces family issues. It could be seen from the opinion from Respondent 3.

"It happens a lot, most people know that it happens to a family with problems, that has family issues and involved in social problems."

(Respondent 3)

Based on data from Respondent 3, it is aligned with research by Elmi Azlina et al. (2015) that stated the factor of pressure in an individual itself and the surrounding within themselves that pushes them to this disgusting act. This also explains that a family plays an important role in creating a harmonious and safe environment so this wouldn't happen in a family institution. Failure in establishing a family institution not only causes the cases of incest to worsen, but it also impacts to children's life. This is because, according to Faizal and Zaki (2014), failed family institution due to parents' negligence in educating children towards a perfect life will lead them to an unhealthy social life. Hence, a bad condition of a family will contribute to social problems.

\section{Sources in Getting Information on Incest}

A lot of sources could be used by students to gain information and knowledge either formally or informally. According to Oh (2012), information is the core to the evolution of knowledge, a pillar to innovations and sources to knowledgeable society. According to him also, the need of students 
in looking for information, not only for completing their task, it is also for a trigger in ideas and generating more knowledge. This could be explained further that university students should not only gain knowledge for a single objective, but they also have to actively seek additional knowledge to be a more informational person. Among the resources that is used by the respondents to gain information on incest is through internet, school syllabus, TV program and also parents.

i. Internet

Based on the interviews done, all the respondents gain information on incest through the internet. Along with the development of the usage of internet nowadays, social media has also been considered as one of the sources to get news or current issues.

"...Then, I read from the internet.."

(Respondent 1)

"Usually ...because I always browse social media, so I get a lot of information from there. Something like online news".

(Respondent 2)

"The most common is to get from Social Media"

(Respondent 3)

"...but if PDF, when we see it while googling, we'll read it. But actually even if it's a video, we got it from the Facebook, so it's social media".

(Respondent 4)

"..usually I read it from twitter, there are those who share it, then newspaper portal, always read it from there."

(Respondent 5)

Even though information is easy to get from a lot of resources, but all the respondents has made the internet as the main resource and it's easy to gain information about incest. Sutedjo (2002) has defined internet as an International Network that is a really big computer network that consists of small networks that communicate with each other and also reach out to the whole world. This shows clearly that the usage of internet is wide and without boundaries. Based on interviews done, respondent 2,3,4 and 5 gained information on incest through social media. The finding is aligned with the research done by Faridanura (2014) that stated on the appearance of a lot of social media site such as Facebook, Twitter and MySpace has most often than not aid in looking for information regardless generation and age. However, respondent 3 also stated that he did some google search to know deeper on incest. Faradilah et al (2015) stated that media and technology plays an important role in widening the information and educating the society on issues related to social problems. So, it is clear that internet is one of the main mediums that help the students to gain knowledge and information including on incest.

\section{ii. $\quad$ Traditional Media}

Along with this modern era, even though all the respondents uses the internet as the main medium in gaining information, however, there are still a small portion of the respondents still uses the traditional media as a tool to gain information.

According to Faridanura (2014), traditional media is usually used by former society before the existence of internet. According to her again, traditional media covers medium such as 
newspaper, magazines and television. Respondents 3,4 and 5 has stated that other than internet, they also read the newspaper to gain further information on incest.

"The main common is you can get from social media, news and newspaper"

(Respondent 3)

"...usually read a lot from the newspaper, most of the time newspaper"

(Respondent 4)

"Hmmm..maybe from reading sources and maybe aaaa...newspaper"

(Respondent 5)

Not only that, respondent 5 also stated that the programs aired more or less could add on to his knowledge about incest. Other than an addition to knowledge, through the television program, the respondent could know on new cases that involves incest.

"...999 tv program on the television always have this kind of thing. So, it's from these kinds of thing."

(Respondent 5)

iii. School syllabus in School.

Other than informal sources, there are a few respondents that consider the school syllabus taught in school really helps in knowing further about incest. According to respondent 1 , through Islamic Teaching taught in school, she could know more detail on incest. This shows that school syllabus plays an important role in enhancing the student's knowledge. It's also not only to solely enhance knowledge, but also has a role in helping to self-shape an individual. As per the research done by Mohd Khairie and Mohamad Khairi (2016), syllabus of Islamic Studies not only emphasis on 'fardhu ain', but it also encompasses other knowledge that could be applied in our everyday life.

\section{"Since secondary school, we learn Islamic Studies subject."}

(Respondent 1)

\section{iv. Parents}

According to respondent 1, parents also play an important role in giving her knowledge on incest. This is because, parents are also the main agent in ensuring the children get information and knowledge. Even though there are still some parents who feel that the school syllabus is enough to educate their kids to be more knowledgeable, however, informal education is also needed from the parents to be done at home. This is because, according to Abdul Munir et al. (2014), parents are teachers when at home where they function as an educator to the morals of their own kids. Due to that, it's not wrong for the parents to give knowledge on social issues such as incest case to their kids so that they will be alert to their surroundings.

"Then, our own family also inform. I mean parents.."

\section{Conclusion}

(Respondent 1)

As for that, the researcher concludes that the entire respondent has a good sound knowledge on incest. This is because, the data gained shows that the entire respondent could explain well on the definition of incest. They are also aware on incest an issue that is happening in the country lately, because from the interview, all the respondents could tell briefly on incest cases that leaves an impact to them. All the respondents also used various medium to add to their knowledge and follow on incest cases from the internet, newspaper and television program. So, 
INTERNATIONAL JOURNAL OF ACADEMIC RESEARCH IN PROGRESSIVE EDUCATION AND

DEVELOPMENT

Vol. 10, No. 1, 2021, E-ISSN: 2226-6348 @ 2021 HRMARS

students could be the activator to disseminate knowledge on incest issues and have an awareness campaign to every layer of society.

\section{References}

Asmida, A., Nur Fazini Asro, R., \& Sulaiman. (2017). Consensual Incest: The Legal Environment in Malaysia. International Journal for Studies on Children, Women, Elderly \& Disabled, 1, 9-15

Abdul Munir, I., Sahariza, M. S., \& Misnan J. (2014). Analisis Bentuk Didikan Ibu Bapa Bagi Membentuk Sahsiah Cemerlang: Kajian di Sekolah Menengah Kebangsaan Pulau Sebang, Alor Gajah, Melaka. Jurnal Perspektif, 8(2),1-10.

Faisal, A. M. F. (2012). Kepekaan Pelajar UTM terhadap Isu Semasa dan Pengetahuan Am. Universiti Teknologi Malaysia, Skudai

Cossar, J., Brandon, M., Bailey, S., Belderron, P., Biggort, L., \& Sharpe, D. (2013). It Takes a Lot Build Trust. Recognition and Telling. Developing Earlier Routes to Help for Children and Young People. Office of the Children's Commissioner, London

Chua, Y. P. (2006). Kaedah Penyelidikan. McGraw-Hill, Kuala Lumpur.

Faridanura, A. (2014). Penggunaan Laman Rangkaian Sosial (Facebook) dalam Kalangan Guru: Motif dan Kesannya. Universiti Teknologi Malaysia, Skudai

Faradillah, I. O., Hazlin, F. R., Nur Zakira, A. Z., \& Nabilah, N. D. A. (2015). Hubungan Penggunaan Media Sosial dan Penerimaan Mesej Dakwah. Proceeding of the 2nd International Conference on Management and Muamalah, 181-191.

Halstead, J. M., \& Reiss, M. J. (2003). Values in Sex Education: From Principles to Practice. Routledge Farmer, London.

Jennifer, M. F. (2017). A Survey of Student Knowledge about Child Sexual Abuse \& Perceived Readness to Provide Counselling Services. The Jounal of Counselor Preparation \& Supervision, 9(1), 1-31.

Idham, M. Y., Noureen, M. H., Hazariah, Y. R., \& Jeniwaty, M. J. (2015). Social Stigma of Incest $n$ Malaysia. International Academic Research Journal of Social Science, 1(2),112-117.

Ismail, M. T. (2010). Wanita, Isteri dan Rahsia Seksual. Telaga Biru, Kuala Lumpur.

Khairul, M. A. G., \& Nur 'Athiroh, M. T. A. (2017). Kesedaran Agama di Kalangan Belia di Desa KEDA Sodek, Kupang, Kedah: Suatu Kajian Literatur. Al-Hikmah, 9(1), 141-158

Faizal, M., \& Zaki, M. I. (2014). Gejala Hubungan Seks Dalam Kalangan Pelajar: Satu Kajian Kes. Seminar Kebangsaan Integriti Keluarga. Fakulti Psikologi dan Pendidikan, Universiti Malaysia Sabah

Khairie, M. S., \& Khairi, M. H. O. (2016). Kefahaman dan Pengamalan Akhlak dalam Kalangan Pelajar Politeknik Sultan Abdul Halim Muadzam Shah. Proceedings of the ICECRS, 1(1): 663676.

Shafrin, N. A. (2012). Penderaan Seksual: Keperluan Kriteria Pegawai, Punca Penderaan dan Kes Tidak Dilaporkan. SOSIOHUMANIKA, 5(1), 81-92.

Oh, G. B. (2012). Tinjauan Terhadap Saluran Maklumat Akademik Pelajar Tahun Akhir di Sebuah IPT.Tesis. Universiti Teknologi Malaysia.

Pathmanathan, S., \& Hajar, S. A. B. (2010). Implementasi Hak Kanak-Kanak (CRC) di Rumah KanakKanak: Dapatan Kajian Rintis. Penerbit Universiti Malaya, Kuala Lumpur. 
INTERNATIONAL JOURNAL OF ACADEMIC RESEARCH IN PROGRESSIVE EDUCATION AND

DEVELOPMENT

Vol. 10, No. 1, 2021, E-ISSN: 2226-6348 @ 2021 HRMARS

Radford, L., Corral, S., Bradley, C., Fisher, H., Basset, C., Howat, N., \& Collishaw, S. (2011). Child Abuse \& Neglect in the UK Today. NSPCC, London

Hajar, S. A. B., \& Noralina, O. (2010). Seminar Kebangsaan Undang-Undang Kanak-Kanak. Kuala Lumpur

Sutedjo, D. O. (2002). E-Education, Konsep Teknologi dan Aplikasi Internet. Andi Publisher, Yogjakarta.

Vezina, C., Daigneault, I. \& Hebert. M. (2013). Lesson Learned From Child Sexual Abuse Research Prevellence, Outcomes \& Preventive Strategies. Child \& Adolescent Psychiatry \& Mental Health, 7, 22-30.

Warrington, C., Beckett, H., Ackerly, E., Walker, M., \& Allnock, D. (2017). Making Noise, Children's Voices for Positive Charge After Sexual Abuse. University of Bedforshire, Luton. 